\title{
Assessing Working Capital Management and Performance of Listed Manufacturing Firms: Nigeria
} Evidence

\author{
Akinleye G. T., ADEBOBOYE Roseline \\ Department of Accounting, Faculty of Management Sciences, Ekiti State University, Ado-Ekiti, Nigeria \\ gtakinleye@gmail.com, osaboboye@gmail.com
}

\begin{abstract}
This study assessed working capital management and performance of listed manufacturing firms in Nigeria 20 firms were sampled, over 10 years. The study employed static data analyses and panel Granger causality test. Result showed that average collection period exerts insignificant negative effect on return on capital employed of the sampled firms, while average collection period also exerts insignificant negative effect on earnings per share of the sampled firms. The result further showed that, average payment period exerts insignificant positive effect on return on capital employed of the sampled firms, but average payment period exerts insignificant negative effect on earnings per share of the sampled firms. The study concluded that, average collection period and average payment exert insignificant effect on return on capital employed of listed manufacturing firms in Nigeria, also; average collection period and average payment period exert insignificant effect on earnings per share of listed manufacturing firms in Nigeria. Hence manufacturing firms in Nigeria should objectively manage average collection period and also maintain a consistent improvement in return on capital employed and earnings per share of listed manufacturing firms in Nigeria.
\end{abstract}

Keywords: Working Capital Management, Performance, Average Collection Period, Average Payment Period.

\section{Introduction}

Working capital is one major factor upon which stability and survival of a business entity depend. Funds are regarded as the capital needed to start, support a business or as accumulated wealth of a business, which is represented as the assets less liabilities and it is also seen as stock or ownership in a company. Therefore, working capital is the fund used for the daily running of a business. In other words, it is the resources that are liquid in nature which are needed by a business entity to sustain stable cash flow. According Cyert \& March (1963), for a firm to achieve economic success, the firm's resources should be utilized efficiently. Working capital management is sustaining an adequate level of working capital, which is meant for short-term period. Also, working capital management is sustaining adequate liquidity for business survival in short-term period. Niresh (2012) opined that working capital management is important in determining firm's performance. Consequently, working capital management is maintaining sufficient cash flow level to manage its liabilities, which is done in the best interest of shareholders. Working capital management enhances a company's financial position and assist in having a better understanding of how well working capital is performing. Several studies had been conducted on assessing working capital management and performance of listed manufacturing firms across countries over time, observably previous studies measured performance using return on asset, return on equity, gross operating profit and net operating profit.

While working capital management was measured using average collection period, average payment period and these studies revealed that, working capital management exerts significant negative effect on firm's performance, while others revealed insignificant negative effect and examples of these studies are; Lazaridies \& Tryfonidis, 2006; Gill, Biger \& Mathur, 2010; Alipour 2011; Vahid, Elham, Mohsen \& Mohammadreza 2012; Ahmadabadi, Mehrabi \& Yazdi 2013; Senthilmani, 2013; Caballero, Teruel \& Solano 2014; Enqvist, Graham \& Nikkinen 2014; Maria \& Paulo, 2015; Li, 2016. However, other previous studies that proxy performance by return on capital employed and earnings per share revealed that, working capital management exerts significant positive effect on performance, examples of such studies are; Mohammad, 2011; Alavinasab \& Davoudi, 2013; Nduta, 2015; Eya, 2016; Madugba \& Ogbonnaya, 2016. Given the divergence in the result of previous studies, this study analyzed the effect of working capital management variables (average collection period and average payment period) on firm's performance measured by return on capital employed and earning per share. In addition, this study observed that little or no attention was given by previous researchers to the direction of causality of working capital management and performance and no consideration was given to heterogeneity effect across firms in the discourse of working capital management and performance, therefore, this study sampled firms across. 
Sub-sectors of the manufacturing sector and incorporated measures of heterogeneity effect in the analysis, through the use of Least Square Dummy Variable (LSDV) and also employed panel based Granger causality test to track the direction of causality of working capital management and firm's performance. Specifically, this study analyzed:

- Effect of average collection period and average payment period on return on capital employed of listed manufacturing firms in Nigeria.

- Effect of average collection period and average payment period on earnings per share of listed manufacturing firms in Nigeria.

- The direction of causality of working capital variables and performance variables of listed manufacturing firms in Nigeria.

\section{Literature Review}

Working Capital Management: Working capital management is the management of current assets and current liabilities of an organization, interrelationship between them as they affect performance and firm's value (Sunday, Abiola \& Lawrencia, 2012). For a business to be operational, it needs liquid assets which will sustain cash flow, pay wages, salaries, and creditors so as to maintain a functional workforce and sustain regular suppliers. An inefficient Management of components of working capital management (average account receivables, average account payables, and inventories) will cause difficulties for firm's continuing operation and reduction in firm's market value (Yang, 2006).

Firm's Performance: Firm 's performance is how well the firm's overall target have been accomplished Eshna (2017). Firm's performance is a how well a firm has been able to achieve its goals at a specified period. According to Nduta (2015), firm's performance is creating revenue for owners of business from the assets of such business. Firm's performance is used by management of firms to evaluate both the profitability and financial position of the organization. According to Haruna (2016), to properly assess the effect of working capital management on firm's performance, one should carry out such test, by proxy performance using return on asset (ROA), return on equity (ROE), and as well as return on capital employed (ROCE); so as to show clearly, some performance indicators of a firm.

Empirical Review: Lazaridis and Tryfonidis (2006) examined the relationship between working capital management and profitability of firms listed in Athens Stock Exchange. Researchers measured performance using gross operating profit, while working capital management was proxy by accounts receivable days, accounts payable days and days in inventory; data were analyzed using correlation and regression analysis. The result revealed that, there exist statistical relationship between working capital management and the firm's profitability. Researchers concluded that there exists a relationship between working capital management and profitability. Alipour (2011), studied working capital management and corporate profitability of firms listed in Tehran stock exchange. Multiple regression and Pearson correlation was used to analyze data and result revealed that, there exist statistical relationship between working capital management and profitability. Vahid, Elham, Mohsen, Mohammadreza (2012), examined the effect of working capital management on performance of firms listed in Tehran stock exchange. Multiple regression analysis was used to analyze data and result revealed that, working capital management exerts significant effect on firm's performance. Enqvist, Graham and Nikkinen (2014), studied the impact of working capital management on firm profitability in Finland.

Researchers measured working capital management using accounts receivable days, accounts payable days, and days in inventory, while profitability was proxy by return on assets (ROA). Researchers used regression analysis to analyze data and the result revealed that, working capital management exerts significant effect on profitability. Ikpefan, Owolabi, Agwu and Adetula (2014), studied working capital management and profitability of the manufacturing sector in Nigeria. Researchers used correlation and regression analysis to analyze data and result revealed that, working capital management exerts significant effect on profitability. Also, result further revealed existence of unidirectional causality between earnings per share and average collection period, as well as unidirectional causality between earnings per share and average payment period. Hence, the study established a unidirectional causality between performance of listed manufacturing firms and their working capital management. Ogbuji and Ogunyomi (2014) examined working capital management 
policy and financial performance in the Nigerian foods and beverages industry. Descriptive analysis, accounting ratios and Pearson correlation analysis were used to analyze data and result revealed that, there exist statistical relationship between working capital management policy and financial performance.

\section{Methodology}

This study adapted the model used by Madugba and Ogbonnaya (2016), to examined working capital management and financial performance of manufacturing companies in Nigeria. Researchers measured financial performance using earnings per share and return on capital employed, while working capital was proxy by average payment period and average collection period. The model is specified below for simplicity $Y_{t}=\delta_{0}+\delta_{1} A C P_{i t}+\delta_{1} A P P_{i t}+\mu_{i t}-------------------(3.1)$

Where the dependent variables in the model used by Madugba and Ogbonnaya are earnings per share (EPS) and return on capital employed (ROCE), while average collection period (ACP), and average payment period (APP) are independent variables of the model used by Madugba and Ogbonnaya; and the model was modified in this study, to capture average collection period, average payment period, which were used as proxy for working capital management alongside asset tangibility (ATANG) and firm size (FZ) which are control variables of this study (independent variables). While return on capital employed and earnings per share were used to measure performance (Dependent Variables). For simplicity the models (Model 1 and Model 2) are expressed in functional and linear forms below:

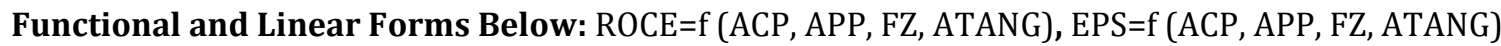
Linear Representation of the Models:

$R O C E_{i t}=\delta_{0}+\delta_{1} A C P_{i t}+\delta_{2} A P P_{i t}+\delta_{3} F Z_{i t}+\delta_{4} A T A N G_{i t}+\mu_{i t}----(3.2)$

$E P S_{i t}=\beta_{0}+\beta_{1} A C P_{i t}+\beta_{2} A P P_{i t}+\beta_{3} F Z_{i t}+\beta_{4} A T A N G_{i t}+\mu_{i t}----(3.3)$

Source(s) of Data and Method of Analysis

This study sample twenty (20) manufacturing firms across sub-sectors of the manufacturing sector in Nigeria. Data were sourced from financial report of firms sampled, for 10 years period (2008-2017). Study made used of correlation matrix, static data analyses (pooled OLS estimator, fixed effect estimator, and random effect estimator), alongside post estimation tests (Restricted F test, Durbin-Wu-Hausman test) and DumitrescuHurlin panel granger causality test.

Analytical Framework: Purposive sampling technique was used to identify study area (Palys, 2008). The models used in this study, were meant to show that the independent variables can cause a change (effect) in the dependent variables, also to test the significance of the population variance (Kothari 2004) and as well as to evaluate the relationship among variables, with significance of beta value at $5 \%$ was interpreted using the probability values (P-value).

\section{Data Analysis and Interpretation}

Table 1: Pooled OLS Estimations

\begin{tabular}{lllll}
\hline Variables & $\begin{array}{l}\text { ROCE } \\
\text { Coefficients } \\
\text { (Estimation value) }\end{array}$ & $\begin{array}{l}\text { Probability } \\
\text { (P value) }\end{array}$ & $\begin{array}{l}\text { EPS } \\
\text { Coefficients } \\
\text { (Estimation value) }\end{array}$ & $\begin{array}{l}\text { Probability } \\
\text { (P value) }\end{array}$ \\
\hline C & 99.38923 & 0.000 & -21.13508 & 0.000 \\
ACP & -.0444249 & 0.216 & -.041477 & 0.004 \\
APP & -.0224948 & 0.259 & -.008617 & 0.274 \\
FZ & -3.807852 & 0.000 & 1.680325 & 0.000 \\
ATANG & 8.5457 & 0.327 & 0.3065035 & 0.929 \\
& R-squared $=0.4235$ & & R-squared $=0.4766$ \\
& Adjusted R-squared $=0.4056$ & F-statistics=10.46 & \\
& F-statistics=6.87 & Probability(F-statistics) $=0.0000$ \\
& Probability(F-statistics) $=0.0000$ & & & \\
& &
\end{tabular}

Source: Authors Computation, (2019) 
Estimation result presented in table 1, showed the effect of average collection period (ACP) and average payment period (APP) on return on capital employed (ROCE) and earnings per share (EPS) when observation across sampled firms was pooled without consideration of their heterogeneity effects. The result of this estimation shows that, both average collection period and average payment period exert insignificant negative effect on return on capital employed with an estimation value of -0.0444249 ( $\mathrm{P}$ value $=0.216>0.05$ ) and -0.0224948 ( $\mathrm{P}$ value $=0.259>0.05$ ) respectively. Result of this estimation also showed that, average collection period exerts a significant negative effect on earnings per share, with an estimation value of 0.041477 ( $\mathrm{P}$ value $=0.004<0.05$ ), while average payment period exerts an insignificant negative effect on earnings per share, with an estimation value of -0.008617 ( $\mathrm{P}$ value $=0.274>0.05$ ). Reported $\mathrm{R}$-squared is 0.4235 and 0.4766 respectively for both models used in this study, and this shows that, there is about $42 \%$ and $48 \%$ systematic variation in return on capital employed and earnings per share respectively of the sampled manufacturing firms, which is explained by the explanatory variables (average collection period, average payment period, asset tangibility and firm size); when no consideration is given to cross-sectional or period effects.

Table 2: Fixed Effect Estimations

\begin{tabular}{|c|c|c|c|c|}
\hline \multirow[b]{2}{*}{ Variables } & \multicolumn{2}{|l|}{ ROCE } & \multicolumn{2}{|l|}{ EPS } \\
\hline & $\begin{array}{l}\text { Coefficients } \\
\text { (Estimation value) }\end{array}$ & $\begin{array}{l}\text { Probability } \\
\text { (P value) }\end{array}$ & $\begin{array}{l}\text { Coefficients } \\
\text { (Estimation) }\end{array}$ & $\begin{array}{l}\text { Probability } \\
\text { (P value) }\end{array}$ \\
\hline $\mathrm{C}$ & 180.4804 & 0.000 & 58.71622 & 0.005 \\
\hline ACP & .0078454 & 0.28 & -.0024489 & 0.870 \\
\hline APP & .0102493 & 0.70 & -.0076449 & 0.327 \\
\hline FZ & -7.095749 & 0.00 & -2.872724 & 0.010 \\
\hline ATANG & -7.432455 & -0.74 & -11.24968 & 0.034 \\
\hline \multicolumn{5}{|l|}{ Fixed Effect } \\
\hline PZ & -42.21667 & 0.000 & -1.430739 & 0.686 \\
\hline GUINNESS & -9.17294 & 0.171 & 9.886159 & 0.006 \\
\hline NB & -4.463051 & 0.544 & 9.508754 & 0.015 \\
\hline DANGSUGAR & -18.0346 & 0.012 & -.7566144 & 0.840 \\
\hline NASCON & -14.03938 & 0.083 & -4.963783 & 0.245 \\
\hline DANGFLOUR & -30.88227 & 0.000 & -.839452 & 0.808 \\
\hline FLOURMILLS & -33.18293 & 0.000 & 1.586439 & 0.668 \\
\hline NESTLE & -1.749751 & 0.784 & 21.22949 & 0.000 \\
\hline VITAFOAM & -34.09788 & 0.000 & -7.896129 & 0.071 \\
\hline CUTIX & -41.23653 & 0.000 & -11.66833 & 0.044 \\
\hline MEYER & 10.7776 & 0.210 & -8.180624 & 0.072 \\
\hline WAPCO & -29.15247 & 0.000 & 7.831068 & 0.038 \\
\hline BERGER & -17.49774 & 0.053 & -9.463424 & 0.047 \\
\hline FIRSTALUM & -61.65237 & 0.000 & -5.30343 & 0.166 \\
\hline PORTPAINT & -4.953228 & 0.637 & -12.89268 & 0.021 \\
\hline BETAGLAS & -45.35556 & 0.000 & -2.813093 & 0.495 \\
\hline PREMPAINT & -57.83856 & 0.000 & -13.52165 & 0.033 \\
\hline PAINTCOM & -58.25469 & 0.000 & -14.63453 & 0.016 \\
\hline DANGCEM & -9.069566 & 0.298 & 33.32579 & 0.000 \\
\hline \multicolumn{3}{|c|}{ R-squared =0.7135 } & \multicolumn{2}{|c|}{ R-squared $=0.5191$} \\
\hline \multicolumn{3}{|c|}{ Adjusted R-squared=0.6760 } & \multicolumn{2}{|c|}{ Adjusted R-squared=0.4563 } \\
\hline \multicolumn{3}{|c|}{ F-statistics $=19.05$} & \multicolumn{2}{|c|}{ F-statistics $=8.26$} \\
\hline \multicolumn{3}{|c|}{ Probability(F-statistics) $=0.0000$} & \multicolumn{2}{|c|}{ Probability $($ F-statistics $)=0.0000$} \\
\hline
\end{tabular}

Source: Authors Computation, (2019)

From table 2, fixed effect estimations (where heterogeneity effect across manufacturing firms sampled, is incorporated into the models in form of intercept term), shows that, average collection period and average payment period exert insignificant positive effect on return on capital employed with an estimation value of $0.0078454(\mathrm{P}$ value $=0.28>0.05)$ and $0.0102493(\mathrm{P}$ value $=0.70>0.05)$ respectively. While average collection period and average payment period exert insignificant negative effect on earnings per share with an 
estimation value of $-0.00244 S 89$ ( $\mathrm{P}$ value $=0.870>0.05$ ), and -0.0076449 ( $\mathrm{P}$ value $=0.327>0.05$ ) respectively. Reported R-squared is 0.7135 and 0.5191 respectively for both models used in the study and this shows $71 \%$ and $52 \%$ systematic variation in return on capital employed and earnings per share respectively, which is explained by the explanatory variables (average collection period, average payment period, asset tangibility and firm size); when consideration is given to cross-sectional or period effects.

Table 3: Random Effect Estimation

\begin{tabular}{lllll}
\hline Variables & $\begin{array}{l}\text { ROCE } \\
\text { Coefficients } \\
\text { (Estimation value) }\end{array}$ & $\begin{array}{l}\text { Probability } \\
\text { (P value) }\end{array}$ & $\begin{array}{l}\text { EPS } \\
\text { Coefficients } \\
\text { (Estimation value) }\end{array}$ & $\begin{array}{l}\text { Probability } \\
\text { (P value) }\end{array}$ \\
\hline C & 123.6965 & 0.000 & -6.03388 & 0.551 \\
ACP & -.0012929 & 0.963 & -.0201144 & 0.164 \\
APP & .0069463 & 0.632 & -.0094842 & 0.218 \\
FZ & -5.30036 & 0.001 & .7943013 & 0.164 \\
ATANG & -2.212385 & 0.809 & -2.858026 & 0.519 \\
& R-squared $=0.6643$ & & R-squared $=0.6570$ & \\
& Wald chi2=13.05 & & Wald chi2 $=15.13$ & \\
& Probability(chi2) $=0.0110$ & Probability (chi2) $=0.0045$ \\
\hline
\end{tabular}

Source: Authors Computation, (2019)

Table 3, Random effect estimation result (when heterogeneity effect across manufacturing firms sampled in the study and overtime period covered was incorporated into the model via the error term), showed that; average collection period exerts insignificant negative effect on return on capital employed, with an estimation value of -0.0012929 ( $P$ value $=0.963>0.05$ ) and average payment period exerts insignificant positive effect on return on capital employed with an estimation value of 0.0069463 ( $\mathrm{P}$ value $=0.632>0.05$ ). While average collection period and average payment period exert insignificant negative effect on earnings per share with an estimation value of -.0201144 ( $\mathrm{P}$ value $=0.164>0.05$ ) and -.0094842 ( $\mathrm{P}$ value $=0.218>0.05$ ) respectively. Reported R-squared is 0.6643 and 0.6570 for both models used in the study, with $66 \%$ and $66 \%$ systematic variation in return on capital employed and earnings per share respectively; which is explained by explanatory variables (average collection period, average payment period asset tangibility and firm size); when heterogeneity effect is subsumed into the error term.

\section{Post Estimation Test}

Table 4: Restricted F Test (Heterogeneity Effect)

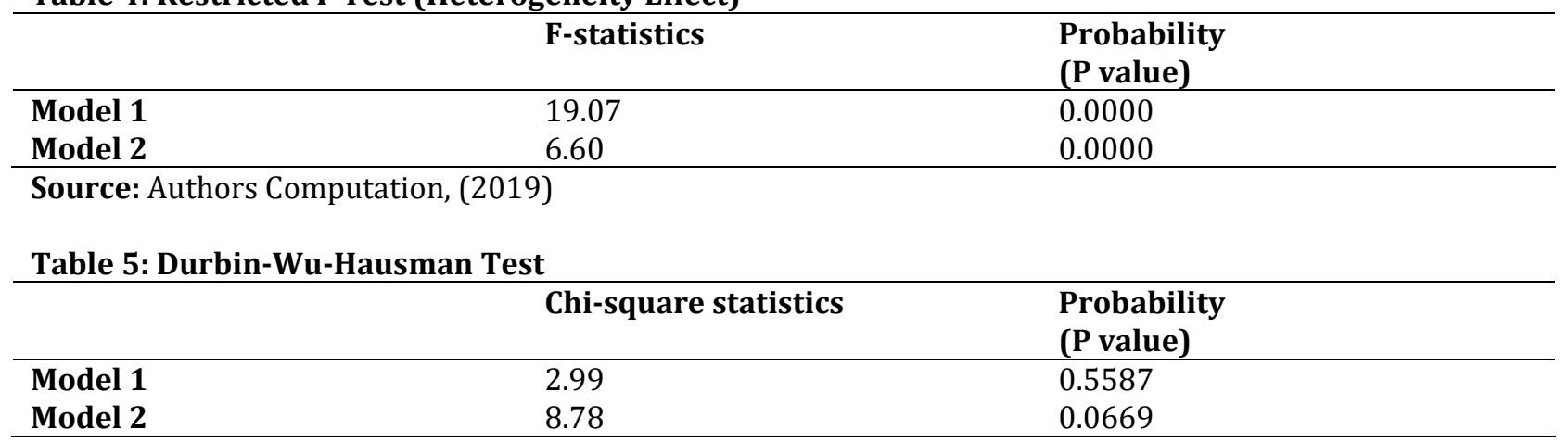

Source: Authors Computation, (2019)

Post estimation test result shown in table 4 (Restricted $\mathrm{F}$ test) shows the justification for incorporating heterogeneity effect in form of intercept term into the models (Model 1 and Model 2), with a statistical significance of 19.07 (P value $=0.0000<0.05$ ) and 6.60 (P value $=0.0000<0.05$ ) respectively. Durbin-WuHausman test result shown in table 5 revealed that, there is not sufficient evidence available to reject the null hypothesis at $56 \%$ (P value $=0.5587>0.05)$ and $7 \%(0.0669>0.05)$ confidence level for the models and this 
means that, the most consistent and efficient estimator for model 1 and model 2 is the random effect estimator.

Table 6: Dumitrescu-Hurlin Panel Granger Causality Test Result

\begin{tabular}{|c|c|c|c|}
\hline Null hypothesis & $\begin{array}{l}\text { Wbar Statistics } \\
\text { (Wald Statistics) }\end{array}$ & $\begin{array}{ll}\text { Zbar } & \text { tilde } \\
\text { Statistics } & \end{array}$ & $\begin{array}{l}\text { Probability } \\
\text { (P value) }\end{array}$ \\
\hline ACP does not granger-causes ROCE & 1.5446 & 1.7223 & 0.0850 \\
\hline ROCE does not granger-causes ACP & $2.2969^{*}$ & $4.1011^{*}$ & 0.0000 \\
\hline APP does not granger-causes ROCE & 1.1987 & 0.6285 & 0.5297 \\
\hline ROCE does not granger-causes APP & 1.5057 & 1.5991 & 0.1098 \\
\hline Null hypothesis & $\begin{array}{l}\text { Wbar Statistics } \\
\text { (Wald statistics) }\end{array}$ & $\begin{array}{l}\text { Zbar tilde } \\
\text { Statistics }\end{array}$ & $\begin{array}{l}\text { Probability } \\
\text { (P value) }\end{array}$ \\
\hline ACP does not granger-causes EPS & 0.8490 & -0.4773 & 0.6331 \\
\hline EPS does not granger-causes ACP & $2.6070^{*}$ & $5.0817^{*}$ & 0.0000 \\
\hline APP does not granger-causes EPS & 1.5701 & 1.8030 & 0.0714 \\
\hline EPS does not granger-causes APP & $2.0176^{*}$ & $3.2178^{*}$ & 0.0013 \\
\hline
\end{tabular}

Note: * connote rejection of the null hypothesis at $5 \%$ significance level

Source: Authors Computation, (2019)

Dumitrescu-Hurlin panel granger causality test result shown in table 6, shows that, there is sufficient evidence to reject the null hypothesis, which states that; return on capital employed does not granger-causes average collection period, which means that, there is the existence of unidirectional causality between return on capital employed and average collection period. Result also showed that there is sufficient evidence to reject the null hypotheses which state that, earnings per share does not granger-causes average collection period and also, earnings per share does not granger-causes average payment period. This is to say that, there is the existence of unidirectional causality between earnings per share and average collection period as well as unidirectional causality between earnings per share and average payment period.

Discussion: Based on the random effect estimation result, average collection period exerts an insignificant negative effect on return on capital employed, with estimation value of -0.0012929 ( $\mathrm{P}$ value $=0.963>0.05$ ). The result revealed that, reduction in average collection period by one day will culminate into about $0.001 \%$ increase in return on capital employed of manufacturing firms sampled in the study. Also, average payment period exerts an insignificant positive effect on return on capital employed, with estimation value of 0.0069463 ( $\mathrm{P}$ value $=0.632>0.05$ ). This means that, increase in average payment period by one day will culminate into about by $0.007 \%$ increase in return on capital employed of manufacturing firms sampled in the study. It also revealed that, average collection period exerts insignificant negative effect on earnings per share, with estimation value of -0.0201144 ( $\mathrm{P}$ value $=0.164>0.05$ ), which means that every one day reduction in average collection period will culminate into about 0.02 naira (2 kobos) increase in earnings per share and average payment period exerts insignificant effect on earnings per share, with estimation value of -0.0094842 ( $\mathrm{P}$ value $=0.218>0.05$ ), which means that, for every one day increase in average payment period, earnings per share will decline insignificantly by 0.009 nairas (less than 1 kobo).

Also result of Dumitrescu-Hurlin panel granger causality test revealed existence of unidirectional causality between return on capital employed and average collection period, which means that, previous level of return on capital employed, exerts significant effect on the current average collection period of manufacturing firms sampled in the study. Also, the result further revealed existence of unidirectional causality between earnings per share and average collection period, as well as unidirectional causality between earnings per share and average payment period. Hence, the study established a unidirectional causality between performance of quoted manufacturing firms and their working capital management. Observably, findings made in this study are in congruence with findings of previous researchers, who in the study of working capital management and performance, revealed that, there is no statistical significant relationship between working capital management variables (average collection period and average payment period) and performance. Examples 
of such studies are Gill et al. (2010), Vahid et al. (2012), Ahmadabadi et al. (2013), Nyabenga (2014) and Mbawuni et al. (2016). While other previous researchers like Madugba and Ogbonnaya (2016), revealed that, average collection period exerts negative effect on both return on capital employed and earnings per share of manufacturing firms and this, is also in congruence with the findings of this study.

\section{Conclusion and Recommendations}

Result revealed that, managing working capital through average collection period can mildly improve firm's performance, when firm's performance is proxy by return on capital employed and earnings per share. While, managing working capital through average payment period has an infinitesimal negative effect on firm's performance which is proxy by earnings per share and return on capital employed. This study also established existence of unidirectional causality between performance of listed manufacturing firms and working capital management, so manufacturing firms in Nigeria should objectively reduce the number of average collection period in a bit to manage working capital needed for effective and efficient firm's operation because such reduction contributes to improved performance, which is proxy by return on capital employed and earnings per share. Also, they should consistently maintain an improved performance (return on capital employed and earnings per share) so as to position the organization for better working capital management in the subsequent years, given the existence of unidirectional causality between performance variables and working capital management variables.

\section{References}

Ahmadabadi, M. R., Mehrabi, E. \& Yazdi, A. F. (2013). Impact of working capital management on the performance of the firms listed on Tehran stock exchange, International journal of academic research in accounting, finance and management science, 3(3), 352-364.

Alavinasab, M. \& Davoudi, E. (2013). Studying the relationship between working capital management and profitability of listed companies in Tehran stock exchange, Business management dynamics, 2(7), 1-8.

Alipour, M. (2011). Working capital management and corporate profitability: Evidence from Iran, World applied science journal, 12(7), 1093-1099.

Aluko, M. A. O., Akinola, G. O. \& Fatokun, S. (2004). Globalization and the manufacturing sector, Journal of social sciences, 9(2), 119-130.

Caballero, S. B., Teruel, P. J. G. \& Salano, P. M. (2014). Working capital management, corporate performance and financial constraints in the United Kingdom, Journal of business research, 67, 332-338.

Cyert, R. M. \& March, J. G. (1963). A behavioral theory of the firm, ( $2^{\text {nd }}$ ed.).

Dyah, P. (2015). The effect of changes in return on assets, return on equity and economic value added to the stock price changes and its impact on earnings per share, Research journal of finance and accounting, 6(6) 80-89.

Enqvist, J., Graham, M. \& Nikkinen, J. (2014). Impact of working capital management on firm profitability in different business cycles: Evidence from Finland, Research international business and finance, 32, 3649.

Eshan, V. (2017). Financial performance- understanding its concept and importance, Simplilearn.

Eya, C. I. (2016). Effect of working capital management on the performance of food and beverage industries in Nigeria, an Arabian journal of business and management review, 6(5), 1-7.

Gill, A., Biger, N. \& Mathur, N. (2010). The relationship between working capital management and profitability: Evidence from the United States, Business and economics journal, 10, 1-9.

Haruna, A. M. (2016). Effects of working capital management on the performance of small and medium enterprises in Nigeria. Doctorate's thesis submitted to Jomo Kenyatta University of agriculture and technology Juja, Kenya.

Ikpefan, O. A., Owolabi, F., Agwu, M. E. \& Adetula, D. T. (2014). Working capital management and profitability of the manufacturing sector: An empirical investigation of Nestle Nigeria Plc and Cadbury Nigeria Plc, European journal of business and social sciences, 3(6), 23-34.

Kothari, C. R. (2004). Sampling techniques, Research methodology, (2 ${ }^{\text {nd }}$ revised ed., 56-68). New Delhi, India: New age international (P) limited publishers. 
Lazaridis, I. \& Tryfonidis, D. (2006). The relationship between working capital management and profitability of listed companies on Athens stock exchange, Journal of financial management and analysis, 19(1), 26-35.

Li, Q. (2016). Working capital management and its effect on the profitability of Chinese listed firms. Master's thesis submitted to ISCTE business school, China.

Madugba, J. U. \& Ogbonnaya, A. K. (2016). Working capital management and financial performance: Evidence from manufacturing companies in Nigeria, European journal of accounting, auditing, and finance research, 4(9), 98-106.

Maria, A. P. \& Paulo, M. G. (2015). Working capital management and SMEs profitability: Portuguese evidence, International Journal of managerial finance, 11(3), 341-358.

Mohammad, M. R. (2011). Working capital management and profitability: A study on the textiles industry, ASA university review, 5(1), 116-132.

Nduta, M. W. (2015). The effect of working capital management on the financial performance of manufacturing firms listed in Nairobi security exchange. Master's thesis submitted to the University of Nairobi schools of business, Kenya.

Niresh, J. A. (2012). Working capital management and financial performance of the manufacturing sector in Sri Lanka, European journal of business and management, 4(5), 1905-2222.

Nyamweno, C. N. \& Olweny, T. (2014). Effect of working capital management on the performance of firms listed at the Nairobi securities exchange, Economics, and finance review, 3(11), 1-14.

Ogbuji, I. \& Ogunyomi, O. O. (2014). Working capital management policy and financial performance in Nigeria foods and beverages industry: A study of Nestle Nigeria Plc, Journal of finance and accounting, 5(20), 48-63.

Palys, T. (2008). Purposive sampling, the sage encyclopedia of qualitative research methods, 2, 697-698.

Raymond, A. E., Adigwe, P. K. \& John-Akamelu, R. C. (2015). The credit management on liquidity and profitability position of a manufacturing company in Nigeria, European journal of research and reflection in management sciences, 3(3), 32-48.

Senthilmani, T. (2013). Impact of working capital management on profitability in the UK manufacturing industry. Master's thesis submitted to London South bank university-business, UK.

Sunday, E. O., Abiola, I. \& Lawrencia, O. O. (2012). Working capital management, firm's performance, and market valuation in Nigeria, World academy of science, engineering and technology, 2, 20-29.

Vahid, T. K., Ealham, G., Mohsen, A. K. \& Mohammadreza, E. (2012). Working capital management and corporate performance: Evidence from Iranian companies, Social and behavioral sciences, 62, 13131318.

Yang, Z. (2006). Data envelopment analysis evaluation of Canadian resource companies, Paper Presented at the Portland International conference on management of Engineering and Technology. 